\title{
Pharmacokinetic - pharmacodynamic model and ampicillin residue depletion after intramammary administration in cows
}

\author{
Artur Burmańczuk, Zbigniew Roliński, \\ Cezary Kowalski, Rafał Zań \\ Sub-Department of Pharmacology, Department of Preclinical Veterinary Sciences \\ Faculty of Veterinary Medicine, University of Life Sciences in Lublin, 20-033 Lublin, Poland \\ artur.burmanczuk@up.lublin.pl
}

Received: December 11, 2015 Accepted: May 16, 2016

\begin{abstract}
Introduction: The objective of this study was to describe a pharmacokinetic-pharmacodynamic (PK/PD) approach for determination of a rational dosage of ampicillin (AMP) and depletion of the antibiotic residues in milk after intramammary administration to cows. Material and Methods: The cows came from different farms from the Lublin Province area. They $(\mathrm{n}=9)$ received $5 \mathrm{~g}$ of the drug, containing $75 \mathrm{mg}$ of AMP sodium in physiological solution, through a syringe tube by intramammary administration. Following single intramammary administration, the milk samples $(5 \mathrm{~mL})$ were collected after 2,4 , $6,8,10,24,36,48$, and $60 \mathrm{~h}$. The liquid chromatography-mass spectrometry analysis was performed on the Agilent 1200 system connected to an AB Sciex API $4000^{\mathrm{TM}}$ mass spectrometer. The pharmacokinetic analysis of the concentrations of the antibiotic in milk was performed using software Phoenix ${ }^{\circledR}$ WinNonlin ${ }^{\circledR}$ 6.4. Calculations were made in non-compartmental (slopes, highest, amounts, and moments) and compartmental analysis. Results: The pharmacokinetic characteristics of AMP after intramammary administration indicate rapid elimination of the drug from milk. The mean residence time had a several-fold lower value than the designated elimination half-life and amounts to only $3.4 \mathrm{~h}$. The concentration of the drug in the milk dropped relatively quickly and the process was very dynamic. Conclusion: The conducted research confirms the rationale of using the PK/PD model in order to verify the dosing regimen for other antibiotic groups and various indicators of the applied PK/PD model.
\end{abstract}

Keywords: cows, milk, ampicillin, intramammary administration, medicinal properties, residues.

\section{Introduction}

Inflammation of the mammary gland in cows is an important sanitary-epidemiological and economical issue (18). A principle in the treatment of mastitis is the introduction of therapeutic agents into the mammary gland quarters devoid of inflammatory secretions, if not accompanied by inflammation of the overall reaction system. Antibiotics should only be used when justified, due to the fact that any abuse may cause unintended reactions, regardless of the general contraindications concerning introduction thereof to the environment $(2$, 5). A number of veterinary products containing $\beta$-lactam antibiotics are used to control mastitis in cows. Among them are aminopenicillins, which include, for example, ampicillin $(2,5,17,21)$.
Ampicillin is commonly used in veterinary medicine due to its broader spectrum when confronted with natural penicillins, low treatment cost, and safety. Compared to penicillins $\mathrm{G}$, ampicillin has a better ability to penetrate the external layer of cell membrane and, subsequently, has a much broader spectrum of activity against many Gram-negative bacteria (e.g. Enterobacteriaceae family) (20). A significant limitation in its therapeutic usage is the increasing antibiotic resistance to aminopenicillins. Therefore, in order to reduce the number of unsuccessful therapies resulting from antibiotic resistance, a combination of pharmacokinetics/pharmacodynamics parameters (PK/PD), i.e. a PK/PD model, has been introduced in human and veterinary medicine $(14,26)$. The PK/PD parameters used in this model include AUC/MIC, time 
of retention of the antibiotic above the minimal inhibitory concentration (MIC) value $\% \mathrm{~T}>\mathrm{MIC}$, and Cmax/MIC. In the case of antibiotics whose effect depends on how much time the concentration remains above the MIC level ( $\beta$-lactams, macrolides), the role of $\% \mathrm{~T}>\mathrm{MIC}$ is decisive for predicting their efficacy. For these antibiotics, the $\% \mathrm{~T}>\mathrm{MIC}$ values should reach $50 \%-80 \%$ after the first and next doses (30).

Inappropriate use of ampicillin in animal treatment may result in the presence of antibiotic residues in food of animal origin. Antibiotic residues in milk produced by cows treated pose a risk to human health $(5,14,18)$. Given the potential threat to human health, the European Commission established maximal residue limits (MRL) for ampicillin in milk (4 $\mu \mathrm{g} / \mathrm{kg})(11)$. Therefore, particular attention was paid to the introduction of selective analytical methods for monitoring antibiotic residues in milk. Additionally, pharmacokinetic studies with ampicillin agents for determination of the withdrawal periods were conducted. The pharmacokinetic profile of ampicillin has been presented in several publications $(6-9,12,13$, $23,25)$. Ampicillin has been studied on alpacas, llamas $(4,23,24)$, lactating sheep and goats (9), cattle (16), female buffaloes (22), and neonatal calves (13). However, up to now, there has been no research on ampicillin pharmacokinetics in cow's udder after single intramammary administration. The additional objective of this study was to describe a PK/PD approach for determination of a rational dosage of ampicillin and depletion of the antibiotic residues in milk.

\section{Material and Methods}

The study was conducted on Polish Black-White dairy cows $(n=9)$ at the age of $4-10$ years with inflammation of the mammary gland. The cows, coming from different farms from the Lublin Province area, were qualified for the research on guidance from the owners. The animals were verified using the Draminski Mastitis Detector 4×4Q (Dramiński ${ }^{\circledR}$, Poland), a four-quarter device for detecting subclinical mastitis in its earliest, visually undetectable stage, in order to assess the somatic cell count. The cows with a somatic cell count $\geq 400000 / \mathrm{mL}$ were classified for the study. They received intramammary $5 \mathrm{~g}$ of the drug, containing $75 \mathrm{mg}$ of ampicillin sodium in physiological solution, in a syringe tube. Internal standard (IS) of sulfafenazole was from Sigma-Aldrich (USA). The antibiotic was used lege artis. Before the collection of milk samples, the teats were cleaned and immersed in a liquid disinfectant-Avitaderm (Agrovet, Poland). Afterwards, teat mouths were wiped with a swab soaked in $70 \%$ ethanol. Milk samples $(5 \mathrm{~mL})$ were collected after 2, 4, 6, 8, 10, 24, 36, 48, and $60 \mathrm{~h}$ after antibiotic administration. The milk samples were transferred into dark plastic bottles and kept in a cooler with ice until transported to laboratory.
In order to examine the efficacy of the ampicillin under in vitro conditions in mastitis cases, the PK/PD model was used. The model was implemented based on the pharmacokinetic analysis of ampicillin concentration in cows' milk. Additionally, \% $>$ MIC was used as a pharmacokinetic indicator. The $\% \mathrm{~T}>\mathrm{MIC}$ is the best prognostic indicator of the potential efficacy of antibiotics (e.g. $\beta$-lactamase), whose antibacterial effect depends on the time of action in an infected site.

Liquid chromatography-mass spectrometry (LC-MS/MS). LC-MS/MS analysis was performed using the Agilent 1200 LC system (Agilent Technologies, Germany) connected to an AB Sciex API $4000^{\mathrm{TM}}$ mass spectrometer (AB Sciex, Canada). The chromatographic separation was performed on the Luna ${ }^{\circledR}$ octadecyl $(\mathrm{C} 18)$ column $(150 \times 2.0 \mathrm{~mm}, 3 \mu \mathrm{m})$ (Phenomenex) coupled with an octadecyl guard column $(2 \times 4 \mathrm{~mm})$ (Phenomenex), which was maintained at $30^{\circ} \mathrm{C}$. The flow rate of the mobile phase was $250 \mu \mathrm{L}$ per min, whilst the injection volume was $30 \mu \mathrm{L}$. The optimal composition of mobile phases $\mathrm{A}$ and $\mathrm{B}$ consisted of acetonitrile (A) and $0.025 \%$ heptafluorobutyric acid (HFBA) (B). The mobile phase gradient programme started at $95 \%$ of $\mathrm{B}$, decreased to $60 \%$ of B for $2 \mathrm{~min}$, and then to $10 \%$ of B for 9 min held for $2 \mathrm{~min}$. After $11 \mathrm{~min}$ it was returned to the initial composition and equilibrated for another $14 \mathrm{~min}$ before the next injection.

Ampicillin analytical method. Ampicillin was extracted from $2 \mathrm{~g}$ of milk sample with $8 \mathrm{~mL}$ of acetonitrile. The IS was added before sample extraction, left to incubate at $4{ }^{\circ} \mathrm{C}$ in the dark for 30 min, mixed with a vortex mixer for $1 \mathrm{~min}$, mechanically shaken for $10 \mathrm{~min}$, and then centrifuged at $1856 \times \mathrm{g}$ for $10 \mathrm{~min}$ at $5^{\circ} \mathrm{C}$. Six millilitres of the supernatant were transferred to glass tubes and placed in a nitrogen evaporator at $45^{\circ} \mathrm{C}$ to dryness. The dry residues were dissolved in $600 \mu \mathrm{L}$ of $0.025 \% \mathrm{HFBA}$ and filtered through $0.45 \mathrm{~mm}$ PVDF syringe filters into chromatographic vials $(500 \mu \mathrm{L})$.

Pharmacokinetics and statistical analysis. The pharmacokinetic analysis of milk concentrations of the antibiotic was performed using the software Phoenix ${ }^{\circledR}$ WinNonlin $^{\circledR} 6.4$ (Certara L.P., USA). Calculations were carried out regardless of the compartmental model in the range of slopes, highest, amounts, and moments (SHAM) analysis. In the SHAM analysis, the following were calculated: $\mathrm{AUC}_{0-\mathrm{t}}$ - area under the curve calculated between zero and the last sampling point; $\mathrm{AUC}_{0 \text {-inf }}$ - area under the curve calculated between zero and infinity; $\mathrm{AUMC}_{0-\mathrm{t}}$ - area under the first moment of curve calculated between zero and the last sampling point; $\mathrm{AUMC}_{0 \text {-inf }}$ - area under the first moment of curve calculated between zero and infinity; $\mathrm{MRT}_{0-\mathrm{t}}$ mean residence time calculated for the last sampling point; $\mathrm{MRT}_{0 \text {-inf }}-$ mean residence time calculated for infinity; $\mathrm{AUC}_{\mathrm{rest}} \%$ - percentage of the rest area under the curve; $\mathrm{C}_{\max }-$ maximal concentration; $\mathrm{t}_{\max }$ - time to rich maximal concentration; $\mathrm{C}_{\text {last }}-$ the last measured 
concentration; $t_{\text {last }}-$ time of the last measured concentration $(15,16,22,27)$.

A two-compartment model of the distribution of ampicillin in the cow's udder was also proposed. The teat canal and a teat cistern (milk compartment) were determined as the first compartment. The second compartment was the udder tissue compartment (tissue compartment). Within the compartment kinetics, the following were calculated: $\mathrm{k}_{\mathrm{el}}$ - elimination rate constant (from the last three concentrations); $\mathrm{k}_{\mathrm{d}}-$ distribution rate constant; $t_{1 / 2 \mathrm{kel}}$ - elimination half-life; $\mathrm{t}_{1 / 2 \mathrm{kd}}-$ distribution half-life; $\mathrm{B}-$ concentration extrapolated by elimination phase; $\mathrm{A}$ - concentration extrapolated by distribution phase; $\mathrm{C}_{0}-$ zero concentration; $\mathrm{k}_{10}$ - elimination rate from milk compartment; $\mathrm{k}_{20}$ - elimination rate from tissue compartment; $\mathrm{k}_{12}$ - rate constant between milk and tissue concentration; $\mathrm{k}_{21}$ - rate constant between tissue and milk concentration; $\mathrm{CL}$ - total clearance; $\mathrm{V}_{1}$ - milk compartment volume; $\mathrm{V}_{2}$ - tissue compartment $(17,19$, $22,28)$.
Assessment of ampicillin efficacy under in vitro conditions with the PK/PD model. The assessment of ampicillin efficacy under in vitro conditions was performed with the $\% \mathrm{~T}>\mathrm{MIC}$ rate in relation to MIC values acquired from references for isolates from mastitis cases and adequate referential strains $(1,3,29)$. Under the experimental conditions, the $\% \mathrm{~T}>\mathrm{MIC}$ rate was based on the assumption that, in a restricted period $\left(\mathrm{T}_{0}-\mathrm{T}_{60}\right)$ expressed in percentages (with assumption $\% \mathrm{~T}_{0}-\mathrm{T}_{60}>\mathrm{MIC}=100 \%$ ), the ampicillin concentrations should exceed MIC values.

\section{Results}

During the experiment, all cows were clinically healthy and no adverse reactions were observed. The results of chromatographic measurements of ampicillin in cows' milk after single intramammary administration are shown in Table 1 and Fig. 1.

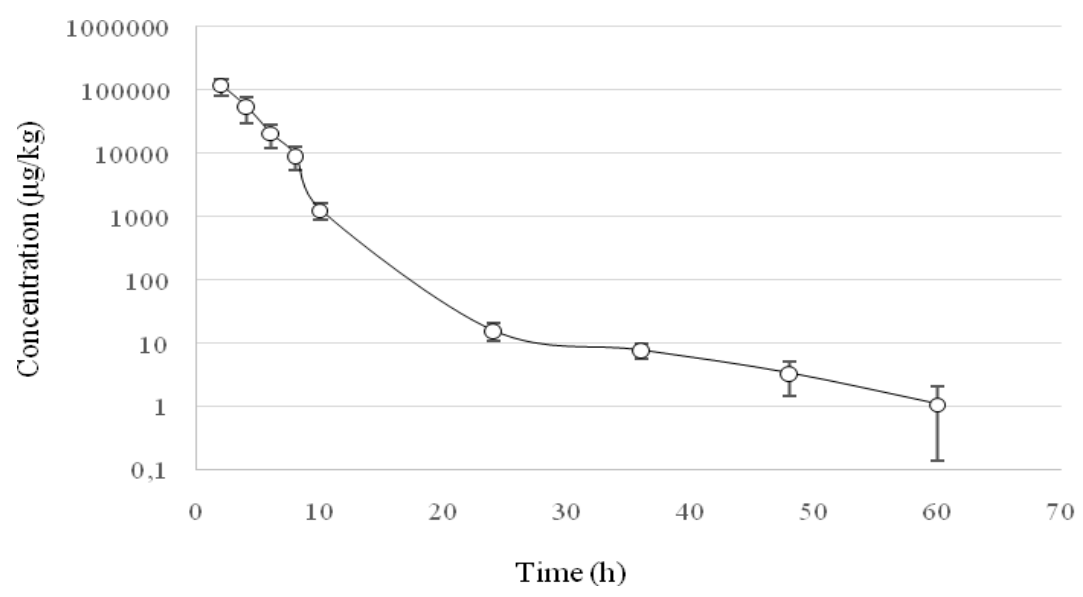

Fig. 1. Semilogarithmic plot of the ampicillin concentration $( \pm \mathrm{SD})$ in milk at different time intervals

Table 1. Concentrations of ampicillin in milk after intramammary administration

\begin{tabular}{|c|c|c|c|c|c|c|c|c|c|}
\hline \multirow{2}{*}{$\begin{array}{l}\text { Cow } \\
\text { no. }\end{array}$} & \multicolumn{9}{|c|}{ Ampicillin concentration in milk in different periods $(\mu \mathrm{g} / \mathrm{kg})$} \\
\hline & $2 \mathrm{~h}$ & $4 \mathrm{~h}$ & $6 \mathrm{~h}$ & $8 \mathrm{~h}$ & $10 \mathrm{~h}$ & $24 \mathrm{~h}$ & $36 \mathrm{~h}$ & $48 \mathrm{~h}$ & $60 \mathrm{~h}$ \\
\hline 1 & 135000.00 & 34500.00 & 22900.00 & 10700.00 & 1460.00 & 15.94 & 7.44 & 1.47 & 1.10 \\
\hline 2 & 145000.00 & 77600.00 & 21100.00 & 9800.00 & 1370.00 & 6.85 & 4.12 & 2.06 & 0.00 \\
\hline 3 & 144000.00 & 101000.00 & 38200.00 & 12400.00 & 1090.00 & 15.65 & 11.58 & 2.12 & 2.70 \\
\hline 4 & 64000.00 & 27400.00 & 9930.00 & 4100.00 & 560.00 & 12.36 & 6.30 & 2.00 & 0.00 \\
\hline 5 & 134000.00 & 81400.00 & 26100.00 & 14500.00 & 1290.00 & 14.84 & 8.15 & 5.12 & 1.12 \\
\hline 6 & 88500.00 & 41900.00 & 13600.00 & 5600.00 & 1020.00 & 14.95 & 7.10 & 4.56 & 0.21 \\
\hline 7 & 59000.00 & 26000.00 & 8800.00 & 3700.00 & 1060.00 & 19.10 & 9.23 & 5.61 & 2.34 \\
\hline 8 & 152000.00 & 54000.00 & 19900.00 & 8500.00 & 2050.00 & 26.45 & 9.80 & 6.40 & 1.30 \\
\hline 9 & 136500.00 & 44320.00 & 23800.00 & 11200.00 & 1510.00 & 15.76 & 6.16 & 1.05 & 1.12 \\
\hline $\bar{X}$ & 117555.60 & 54235.56 & 20481.11 & 8944.44 & 1267.77 & 15.76 & 7.76 & 3.37 & 1.09 \\
\hline$\pm \mathrm{SD}$ & 36595.29 & 26523.91 & 9070.84 & 3775.94 & 411.63 & 5.21 & 2.22 & 2.02 & 0.95 \\
\hline
\end{tabular}


Pharmacokinetic analysis of the ampicillin concentration in cows' milk after intramammary administration. The pharmacokinetic results are presented in Table 2. The research was carried out within 4.9 half-life's after administration of the drug.

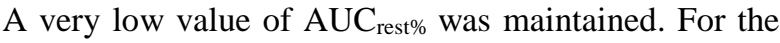
two-compartment model, the curves were classified on the basis of the difference between $\mathrm{k}_{\mathrm{d}}>\mathrm{k}_{\mathrm{el}}$. The $\mathrm{k}_{\mathrm{d}}$ value was more than nine times higher than the $\mathrm{k}_{\mathrm{el}}$, which fully qualified the model for the two-compartment analysis. The elimination half-life calculated on the basis of $\mathrm{k}_{\mathrm{el}}$ determined by $\mathrm{MRT}_{0-\mathrm{t}}$ was about $2.35 \mathrm{~h}$. It was therefore significantly shorter than $t_{1 / 2 \mathrm{kel}}$ determined on the basis of examination of the terminal part of the curve. This also confirmed the correct qualification to the two-compartment model. The two-compartment model and the corresponding rate constants are shown in Fig. 2.
Examination of potential efficacy of ampicillin under in vitro conditions with the PK/PD model. According to the MIC values of aminopenicillins for bacteria isolated from mastitis cases presented in the references $(1,31)$, they are highly diversified and vary within a range of $0.25-32 \mu \mathrm{g} / \mathrm{mL}$. For instance, the MIC values for referential strains are as follows: E. coli (MIC $-2-8 \mu \mathrm{g} / \mathrm{mL}$ ) and $S$. aureus (MIC - 0.5-2 $\mu \mathrm{g} / \mathrm{mL}$ ). Further data are presented in Table 3. It was determined that only in some isolates from mastitic cows, the ampicillin concentrations in the whole period $\mathrm{T}_{0}-\mathrm{T}_{60}$, were higher than the established MIC values for bacteria. Detailed results of the calculated $\% \mathrm{~T}$ (>MIC) indicator values for microorganisms isolated from mastitis cases are presented in Table 4.

Table 2. Pharmacokinetic parameters describing the behaviour of the ampicillin concentrations in the milk after intramammary administration

\begin{tabular}{|c|c|c|c|}
\hline PK parameters & Unit & $\mathrm{M}$ & $\mathrm{SD}$ \\
\hline $\mathrm{AUC}_{0-\mathrm{t}}$ & $\mu \mathrm{g} \times \mathrm{h} / \mathrm{kg}$ & 41292.081 & 13258.718 \\
\hline $\mathrm{AUC}_{0 \text {-inf }}$ & $\mu \mathrm{g} \times \mathrm{h} / \mathrm{kg}$ & 41295.844 & 13259.137 \\
\hline $\mathrm{AUMC}_{0-\mathrm{t}}$ & $\mu \mathrm{g} \times \mathrm{h}^{2} / \mathrm{kg}$ & 1405027.333 & 469828.090 \\
\hline $\mathrm{AUMC}_{0 \text {-inf }}$ & $\mu \mathrm{g} \times \mathrm{h}^{2} / \mathrm{kg}$ & 1408010.342 & 470283.652 \\
\hline $\mathrm{MRT}_{0-\mathrm{t}}$ & $\mathrm{h}$ & 3.391 & 0.097 \\
\hline $\mathrm{MRT}_{0 \text {-inf }}$ & $\mathrm{h}$ & 3.399 & 0.100 \\
\hline $\mathrm{AUC}_{\text {rest } \%}$ & $\%$ & 0.010 & 0.008 \\
\hline $\mathrm{C}_{\max }$ & $\mu \mathrm{g} / \mathrm{kg}$ & 117555.556 & 34502.371 \\
\hline$t_{\max }$ & $\mathrm{h}$ & 2.000 & 0.000 \\
\hline $\mathrm{C}_{\text {last }}$ & $\mu \mathrm{g} / \mathrm{kg}$ & 1.099 & 0.904 \\
\hline $\mathrm{t}_{\text {last }}$ & $\mathrm{h}$ & 60.000 & 0.000 \\
\hline $\mathrm{k}_{\mathrm{el}}$ & $1 / \mathrm{h}$ & 0.05849 & 0.012 \\
\hline$t_{1 / 2 \mathrm{kel}}$ & $\mathrm{h}$ & 12.293 & 2.267 \\
\hline $\mathrm{k}_{\mathrm{d}}$ & $1 / \mathrm{h}$ & 0.57200 & 0.041 \\
\hline$t_{1 / 2 \mathrm{kd}}$ & $\mathrm{h}$ & 1.218 & 0.088 \\
\hline $\mathrm{B}$ & $\mu \mathrm{g} / \mathrm{kg}$ & 64.091 & 24.782 \\
\hline A & $\mu \mathrm{g} / \mathrm{kg}$ & 483815.691 & 213570.989 \\
\hline $\mathrm{C}_{0}$ & $\mu \mathrm{g} / \mathrm{kg}$ & 483879.783 & 213561.546 \\
\hline $\mathrm{k}_{10}$ & $1 / \mathrm{h}$ & 0.57111 & 0.041 \\
\hline $\mathrm{k}_{21}$ & $1 / \mathrm{h}$ & 0.05856 & 0.012 \\
\hline $\mathrm{k}_{12}$ & $1 / \mathrm{h}$ & 0.00082 & 0.000 \\
\hline $\mathrm{k}_{20}$ & $1 / \mathrm{h}$ & 61.956 & 33.849 \\
\hline $\mathrm{CL}$ & $\mathrm{kg} / \mathrm{h}$ & 2.084 & 0.861 \\
\hline $\mathrm{V}_{1}$ & $\mathrm{~kg}$ & 0.192 & 0.095 \\
\hline $\mathrm{V}_{2}$ & $\mathrm{~kg}$ & 15.730 & 9.184 \\
\hline
\end{tabular}

$\mathrm{M}$ - arithmetic mean; SD - standard deviation; $\mathrm{AUC}_{0-\mathrm{t}}$ - area under the curve calculated between zero and the last sampling point; $\mathrm{AUC}_{0 \text {-inf }}$ - area under the curve calculated between zero and infinity; $\mathrm{AUMC}_{0-\mathrm{t}}-$ area under the first moment of curve calculated between zero and the last sampling point; $\mathrm{AUMC}_{0 \text {-inf }}$ - area under the first moment of curve calculated between zero and infinity; $\mathrm{MRT}_{0-\mathrm{t}}-$ mean residence time calculated for the last sampling point; $\mathrm{MRT}_{0 \text {-inf }}-$ mean residence time calculated for infinity; $\mathrm{AUC}_{\text {rest } \%}$ - percentage of the rest area under the curve; $\mathrm{C}_{\max }-$ maximal concentration; $t_{\max }-$ time to rich maximal concentration; $\mathrm{C}_{\text {last }}-$ last measured concentration; $\mathrm{t}_{\text {last }}-$ time of the last measured concentration; $\mathrm{k}_{\mathrm{el}}$ - elimination rate constant; $\mathrm{k}_{\mathrm{d}}$ - distribution rate constant; $\mathrm{t}_{1 / 2 \mathrm{kel}}-$ elimination half-life; $\mathrm{t}_{1 / 2 \mathrm{kd}}$ - distribution half-life; $\mathrm{B}$ - concentration extrapolated by elimination phase; $\mathrm{A}$-concentration extrapolated by distribution phase; $\mathrm{C}_{0}$ - zero concentration; $\mathrm{k}_{10}$ - elimination rate from milk compartment; $\mathrm{k}_{20}-$ elimination rate from tissue compartment; $\mathrm{k}_{12}$ - rate constant between milk and tissue concentration; $\mathrm{k}_{21}-$ rate constant between tissue and milk concentration; $\mathrm{CL}$ - total clearance; $\mathrm{V}_{1}$ - milk compartment volume; $\mathrm{V}_{2}-$ tissue compartment 


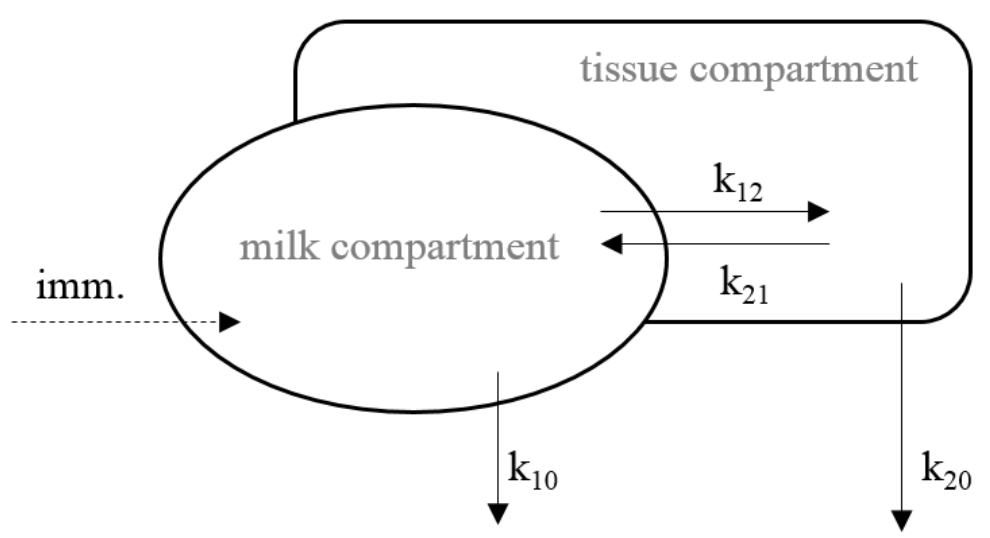

Fig. 2. Two-compartment model of ampicillin elimination

$\mathrm{k}_{10}$ - elimination rate from milk compartment; $\mathrm{k}_{20}$ - elimination rate from tissue compartment; $\mathrm{k}_{12}$ - rate constant between milk and tissue concentration; $\mathrm{k}_{21}$ - rate constant between tissue and milk concentration; imm. - intramammary administration

Table 3. MIC values for isolates from mammary gland inflammation cases in cows (reference data)

\begin{tabular}{llll}
\hline Mastitis isolates & Aminopenicillins & MIC $(\mu \mathrm{g} / \mathrm{mL})$ & Ref. \\
\hline $\begin{array}{l}\text { Referential strains: } \\
\text { E. coli }\end{array}$ & ampicillin & $2-8$ & $(31)$ \\
$\begin{array}{l}\text { Staph. } \text { aureus } \\
\text { Mastitis cases isolates: }\end{array}$ & ampicillin & $0.5-2$ & $(31)$ \\
Enterobacteriaceae & ampicillin & sensitive $<8$ & \\
Staph. spp. & ampicillin & immune $\geq 32$ & \\
& & sensitive $\leq 0.25$ & immune $>0.5$ \\
Str. agalactiae & ampicillin & sensitive $<1.05$ & immune $\geq 3.25$ \\
Staph. epidermidis & ampicillin & sensitive $<13.50$
\end{tabular}

Table 4. Calculated values for $\mathrm{T}_{(0-60)}>\mathrm{MIC}$ under in vitro conditions and analysis of the studied ampicillin concentration after intramammary administration to cows with mastitis (at $\% \mathrm{~T}_{0}-\mathrm{T}_{60}>\mathrm{MIC}=100 \%$ )

\begin{tabular}{|c|c|c|}
\hline Bacterium type and MIC values for ampicillin & Antibiotic & $\begin{array}{l}\text { Time of ampicillin concentration sustenance at: } \\
\% \mathrm{~T}_{0}-\mathrm{T}_{60}>\mathrm{MIC}\end{array}$ \\
\hline \multicolumn{3}{|l|}{ Reference strains: } \\
\hline $\begin{array}{l}\text { E. coli }-2 \mu \mathrm{g} / \mathrm{mL} \\
\text { E. coli }-8 \mu \mathrm{g} / \mathrm{mL}\end{array}$ & $\begin{array}{l}\text { ampicillin } \\
\text { ampicillin }\end{array}$ & $\begin{array}{l}\mathrm{T}=48 \mathrm{~h}-3.37 \pm 2.02-\% \mathrm{~T}=80 \\
\mathrm{~T}=24 \mathrm{~h}-15.76 \pm 5.02-\% \mathrm{~T}=40\end{array}$ \\
\hline $\begin{array}{l}\text { S. aureus }-0.5 \mu \mathrm{g} / \mathrm{mL} \\
\text { S. aureus }-2 \mu \mathrm{g} / \mathrm{mL}\end{array}$ & $\begin{array}{l}\text { ampicillin } \\
\text { ampicillin }\end{array}$ & $\begin{array}{l}\mathrm{T}=60 \mathrm{~h}-1.09 \pm 0.95-\% \mathrm{~T}=100 \\
\mathrm{~T}=48 \mathrm{~h}-3.37 \pm 2.02-\% \mathrm{~T}=80\end{array}$ \\
\hline \multicolumn{3}{|l|}{ Mastitis strains: } \\
\hline $\begin{array}{l}\text { Str. agalactiae }-1.05 \mu \mathrm{g} / \mathrm{mL} \\
\text { Str. agalactiae }-3.25 \mu \mathrm{g} / \mathrm{mL}\end{array}$ & $\begin{array}{l}\text { ampicillin } \\
\text { ampicillin }\end{array}$ & $\begin{array}{l}\mathrm{T}=60 \mathrm{~h}-1.09 \pm 0.95-\% \mathrm{~T}=100 \\
\mathrm{~T}=48 \mathrm{~h}-3.37 \pm 2.02-\% \mathrm{~T}=80\end{array}$ \\
\hline $\begin{array}{l}\text { Staph. spp. }-0.25 \mu \mathrm{g} / \mathrm{mL} \\
\text { Staph. spp. }-0.5 \mu \mathrm{g} / \mathrm{mL}\end{array}$ & $\begin{array}{l}\text { ampicillin } \\
\text { ampicillin }\end{array}$ & $\begin{array}{l}\mathrm{T}=60 \mathrm{~h}-1.09 \pm 0.95-\% \mathrm{~T}=100 \\
\mathrm{~T}=60 \mathrm{~h}-1.75 \pm 1.14-\% \mathrm{~T}=100\end{array}$ \\
\hline $\begin{array}{l}\text { Enterobacteriaceae }-8 \mu \mathrm{g} / \mathrm{mL} \\
\text { Enterobacteriaceae }-32 \mu \mathrm{g} / \mathrm{mL}\end{array}$ & $\begin{array}{l}\text { ampicillin } \\
\text { ampicillin }\end{array}$ & $\begin{array}{l}\mathrm{T}=24 \mathrm{~h}-15.76 \pm 5.02-\% \mathrm{~T}=40 \\
\mathrm{~T}=10 \mathrm{~h}-1267.77 \pm 411.63-\% \mathrm{~T}=16.6\end{array}$ \\
\hline $\begin{array}{l}\text { Staph. epidermidis }-13.50 \mu \mathrm{g} / \mathrm{mL} \\
\text { Staph. epidermidis }-45 \mu \mathrm{g} / \mathrm{mL}\end{array}$ & $\begin{array}{l}\text { ampicillin } \\
\text { ampicillin }\end{array}$ & $\begin{array}{l}\mathrm{T}=24 \mathrm{~h}-15.76 \pm 5.02-\% \mathrm{~T}=40 \\
\mathrm{~T}=10 \mathrm{~h}-1267.77 \pm 411.63-\% \mathrm{~T}=16.6\end{array}$ \\
\hline
\end{tabular}




\section{Discussion}

The pharmacokinetic characteristics of ampicillin after intramammary administration indicate a rapid elimination of the drug from milk. $\mathrm{MRT}_{0-\mathrm{t}}$ has a value many times lower than the determined $t_{1 / 2 \mathrm{kel}}$ and amounts to only $3.4 \mathrm{~h}$. This means that the concentration of the drug in the milk drops relatively quickly and the process is very dynamic. The $t_{1 / 2 \mathrm{kel}}$ for the kinetics of intramammary administration means the sum of all elimination mechanisms that induce the suppression and withdrawal of the drug from the udder. The key elements of this process include transfer of the drug to the udder tissue, transfer of the drug to the entire organism, and elimination of the drug with milk. The proposed model assumes that the transfer to the udder tissue is represented by constant $\mathrm{k}_{12}$, and the transfer from the udder to milk by $\mathrm{k}_{21}$. Based on the calculations, it can be concluded that the transfer of the drug to the udder tissues is a very slow process compared to the reverse process i.e. the transfer from the udder tissue to milk. The rate of the transfer to the udder tissue is an over seventy-fold lower process than the transfer from the udder tissue to milk. This means that a small amount of the drug has a chance to enter the systemic circulation. The rate of elimination from the tissue compartment is expressed by the rate constant $\mathrm{k}_{20}$. This constant indicates rapid elimination of ampicillin from the general circulation. The speed of this process is almost 60 times greater than the elimination with milk; however, it entails a very small fraction of the drug. This means that a key to the elimination of ampicillin after intramammary administration is to eliminate it with milk. This is confirmed by the value of the $\mathrm{k}_{\mathrm{d}}$ to $\mathrm{k}_{10}$ ratio (1.001). $\mathrm{V}_{1}$ indicates the location of the drug in a small volume of milk. The value of $\mathrm{V}_{2}$ indicates a significant proportion of the tissue compartment at the disposal of the drug. It is, however, limited and its size indicates a transfer within the udder. Complete elimination of ampicillin reaching a level of $99.90 \%$ occurs at a time equal to $10 \times t_{1 / 2 \mathrm{kel}}$. This means that assuming linear kinetics of the drug elimination over the time range analysed in this study (up to $60 \mathrm{~h}$ ), ampicillin will be eliminated from the organism at the level of $99.90 \%$ after ca. $123 \mathrm{~h}(5.125 \mathrm{~d})$ post administration.

The observed course of the concentration of ampicillin in the milk on the concentration-time curves is similar to the curve of intravenously administered drugs. Only after intravenous administration can we observe an immediate maximal concentration in plasma. Subsequently, it decreases quickly as a result of distribution. In the case of ampicillin, the concentration-time curve has a steeper course (Fig. 1). After approx. 10 to $24 \mathrm{~h}$, the steep curve slopes for ampicillin decrease and remain curves of perivascularly administered medicines. With relatively low protein binding of ampicillin, the clear decrease in its concentration in cows' milk $4 \mathrm{~h}$ after administration was caused by absorption to mammary gland vesicles and, to a lower extent, by penetration to blood. In addition, after ca. $36 \mathrm{~h}$ from administration of ampicillin, the concentration-time curves were characterised by slow elimination, which lasted up to $60 \mathrm{~h}$. During that time, the concentration of ampicillin exceeded the MRL value. However, after $60 \mathrm{~h}$, the ampicillin level became lower than the MRL value.

There is no available scientific literature on the pharmacokinetics of ampicillin in cows' milk after intramammary administration. Therefore, the results had to be related only to the research taking into consideration intravascularly or intramuscularly administered aminopenicillins. Only the course of the concentration-time curve for milk after intravascular administration of ampicillin $(10,22,23)$ can provide a reliable reference for concentration-time curves after intramammary administration of penicillins. In this investigation, after intramammary administration, ampicillin was detectable in milk for 2-60 h. However, intravenously administered ampicillin $(6 \mathrm{mg} / \mathrm{kg}$ ) in buffalo persisted in milk for only $8 \mathrm{~h}$ (22). Consequently, this confirms the fact that parenterally administered acidic antibiotics are quickly eliminated from milk. In addition, quick aminopenicillin elimination from milk was observed after intravenous administration of this antibiotic in llamas (23). The above-mentioned results of the retention time of ampicillin in milk after intravenous administration indicate limited suitability of the parenteral use of the indicated antibiotic in mastitis treatment.

Pharmacokinetic studies are essential for defining the rational dosing in individual species. Given the existing methodical and selective differences, the comparison of the pharmacokinetic indicators established in our studies on cows with those calculated for different species is unjustified. However, the differences result from the different routes of administration, dosage differences, different analytical techniques, and species characteristics. Therefore, out of necessity, only small differences in the studied indicators describing the behaviour of ampicillin in cows' milk after intramammary administration have been discussed in the literature. The fast rate of elimination with a large decrease in the concentration of ampicillin was recorded $24 \mathrm{~h}$ after administration of the drug. Additionally, at a designated withdrawal period for ampicillin in the milk, the concentrations of the antibiotic residues were lower than the predetermined value MRL, $4 \mu \mathrm{g} / \mathrm{kg}$, within $60 \mathrm{~h}$. Studies have shown variable level of sensitivity of microorganisms isolated from mastitis cases to ampicillin $(1,3,29)$. Based on the literature concerning pathogen sensitivity to aminopenicillins, assessment (under in vitro conditions with the use of $\% \mathrm{~T}>\mathrm{MIC}$ ) of potential efficacy of these antibiotics in mastitis cases was 
performed. The calculated results allow an assumption that during the treatment of mastitis induced by pathogens with low sensitivity to aminopenicillins (for example, MIC - E. coli $-8 \mu \mathrm{g} / \mathrm{mL}$, Enterobacteriaceae $-8 \mu \mathrm{g} / \mathrm{mL}$, Streptococcus epidermidis - $13.50 \mu \mathrm{g} / \mathrm{mL}$ ), the antibiotics should be re-administered already $12 \mathrm{~h}$ after the first administration. In the case of strains with high sensitivity to aminopenicillins (e.g. MIC Staphylococcus aureus - 0.5-2 $\mu \mathrm{g} / \mathrm{mL}$, Staphylococcus spp. - 0.25-0.5 $\mu \mathrm{g} / \mathrm{mL}$, Streptococcus agalactiae 1.05-3.25 $\mu \mathrm{g} / \mathrm{mL}$ ), recommended doses should be sustained. At high MIC values established for highly ampicillin-sensitive pathogens, the regimen of dosing these penicillins ensures maintenance of their concentration above the MIC value (according to $\% \mathrm{~T}>\mathrm{MIC}$ ) for $50 \%-80 \%$ of effective time. The conducted research confirms the rationale of using the $\mathrm{PK} / \mathrm{PD}$ model in order to verify the dosing regimen for other antibiotic groups and various indicators of the applied PK/PD model: AUC/MIC, Cmax/MIC, and $\% \mathrm{~T}>\mathrm{MIC}$.

Conflict of Interests Statement: The authors declare that there is no conflict of interests regarding the publication of this article.

Financial Disclosure Statement: This work was financially supported by the Polish Ministry of Science and Higher Education (NCN Project No. N N308 603 438).

Animal Rights Statement: The experiments on animals were conducted in accordance with the Local Ethical Committee laws and regulations as regards care and use of laboratory animals.

\section{References}

1. Berghash S.R., Davidson J.N., Armstrong J.C., Dunny G.M.: Effects of antibiotic treatment of nonlactating dairy cows on antibiotic resistance patterns of bovine mastitis pathogens. Antimicrob Agents Chemother 1983, 5, 771-776.

2. Burmańczuk, A., Roliński, Z., Kowalski, C., Zań, R.: Concentration of cefacetril in milk after its intramammary administration to cows with health and inflamed mammary gland. Bull Vet Inst Pulawy 2011, 55, 685-688.

3. Cervinkova D., Vlkova H., Borodacova I., Makovcova J., Babak V., Lorencova A., Vrtkova I., Marosevic D., Jaglic Z.: Prevalence of mastitis pathogens in milk from clinically healthy cows. Med Weter 2013, 58, 567-575.

4. Christensen J.M., Smith B.B., Murdena S.B., Hollingshead N.: The disposition of five therapeutically important antimicrobial agents in llamas. J Vet Pharmacol Ther 1996, 19, 43-438.

5. Concordet D., Toutain P.L.: The withdrawal time estimation of veterinary drugs revisited. J Vet Pharmacol Ther 1997, 20, 380-386.

6. Craigmill A.L., Pass M.A., Wetzlich S.: Comparative pharmacokinetics of AMX administered intravenously to sheep and goats. J Vet Pharmacol Ther 1992, 15, 72-77.

7. Delis G.A., Koutsoviti-Papadopoulou M., Siarkou V.I., Kounenis G., Batzias G.C.: Pharmacodynamics of amoxicillin against Mannheimia haemolytica and Pasteurella multocida and pharmacokinetic/pharmacodynamic (PK/PD) correlation in sheep. Res Vet Sci 2010, 89, 418-425.

8. Elsheikh H.A., Taha A., Khalafalla A., Osman I., Wasfi I.: Pharmacokinetics of amoxicillin trihydrate in Desert sheep and Nubian goats. Vet Res Commun 1999, 23, 507-514.

9. Escudero E., Espuny A., Vicente M.S., Cárceles C.M.: Comparative pharmacokinetics of an ampicillin/sulbactam combination administered intramuscularly in lactating sheep and goats. Can J Vet Res 1999, 1, 25-30.

10. Escudero E., Cárceles C.M., Vicente S.: Pharmacokinetics of amoxicillin/clavulanic acid combination and of both drugs alone after intravenous administration to goats. Vet J 1998, 152, 551-559.

11. EMEA. Penicillins Summary Report. Committee for Veterinary Medicinal Products 2008, 1-2.

12. Fernandez C., Modamio P., Mestorino N., Errecalde J.O., Marino E.L.: Pharmacokinetics of sodium and trihydrate amoxycillin in sheep after intravenous and intramuscular administration. J Vet Pharmacol Ther 2007, 30, 263-266.

13. Fernandez-Varon E., Escudero-Pastor E., Carceles-Rodriguez C.: Pharmacokinetics of an ampicillin-sulbactam combination after intravenous and intramuscular administration to neonatal calves. Vet J 2005, 169, 437-443.

14. Frimodt-Moller.: How predictive PK/PD for antibacterial agents. Int J Antimicrob Ag 2002, 4, 333-339.

15. Garg S.K., Chaudhary R.K., Srivastava A.K.: Disposition kinetics and dosage of cephalexin in cow calves following intramuscular administration. Ann Rech Vet 1992, 23, 399-402.

16. Gehring R., Van der Merve D., Pierce A.N, Baynes R.E., Craigmill A.L., Riviere J.E.: Multivariate meta-analysis of pharmacokinetic studies of ampicilin trihydrate in cattle. Am J Vet Res 2005, 66, 108-112.

17. Gibaldi M., Perrier D.: Pharmacokinetics. Marcel Dekker, New York, 1982.

18. Grunt P., Maincent P., Berthelot X., Kaltsatos V.: Bovine mastitis and intramammary drug delivery; review and perspectives. Adv Drug Deliv Rev 2001, 50, 245-259.

19. Guerrini V.H., Filippich L.J, Cao G.R., English P.B., Bourne D.W.: Pharmacokinetics of cefaronide, ceftriaxone, and cefoperazone in sheep. J Vet Pharmacol Ther 1985, 8, $120-127$.

20. Guterbock W.W, Eenennaam A.L, Anderson R.J., Gardner I.A., Cullor J.S., Homberg C.A.: Efficacy of intramammary antibiotic therapy for treatment of clinical mastitis caused by environmental pathogens. J Dairy Sci 1993, 76, 3437-3441.

21. Jacoby G.A., Munoz-Price L.S.: The new beta-lactamases. New Engl J Med 2005, 352, 380-391.

22. Jayachandran C., Singh M.K., Banerjee N.C.: Pharmacokinetics and distribution of ampicillin in plasma, milk and uterine fluid of female buffaloes. Vet Res Commun 1990, 14, 47-51.

23. Kreil V.E., Ambrosa L., Montoyaa L., Hallua R., Rebueltoa M., Bramuglia G.: Pharmacokinetics of sodium and trihydrate amoxicillin after intravenous and intramuscular administration in llamas (Lama glama). Small Ruminant Res 2012, 102, 208-212.

24. Kreil V., Lüders C., Hallu R., Rebuelto M., Betancourt L.: Pharmacokinetics of ampicillin in Alpacas (Lama pacos). Arch Med Vet 2001, 2, 241-246.

25. Li Y., Wang L., Gu x., Zeng Z., He L., Yang F., Yuan B., Shu J., Ding H.: Pharmacokinetics and residues of cefquinome in milk of lactating Chinese dairy cows after intramammary administration. J Integr Agr 2014, 13, 2750-2757.

26. McKeller Q.A., Sanchez Bruni S.F., Jones D.G.: Pharmacokinetic/pharmacodynamic relationships of antimicrobial drug used in veterinary medicine. $J$ Vet Pharmacol Ther 2004, 27, 503-514. 
27. Movassagh M.H., Karami A.R.: Beta-lactam antibiotics residues in pasteurised milk by Beta Star test in the north-west region of Iran. ARPN J Agri Biol Sci 2011, 6, 7-10.

28. Prades M., Brown M.P., Gronwall R., Miles N.S.: Pharmacokinetics of sodium cephapirin in lactating dairy cows. Am J Vet Res 1988, 49, 1888-1894.

29. Rajala-Schultz P.J., Smith K.L., Hogan J.S., Love B.C.: Antimicrobial susceptibility of mastitis pathogens from first lactation and older cows. Vet Microbiol 2004, 102, 33-42.
30. Toutain P.L., del Castillo J.R., Bousquet-Melou, A.: The pharmacokinetic-pharmacodynamic approach to a rational dosage regimen for antibiotics. Res Vet Sci Oct 2002, 73, $105-114$.

31. VET 01-S2: Performance standards for antimicrobial disk and dilution susceptibility tests for bacteria isolated from animals. Sec Inform Suppl 2013, 33, 25-29. 